\title{
A Global Revolutionary Class Will Ride the Tiger of Alienation
}

\author{
Hardy Hanappi \\ University of Technology of Vienna, Institute for Mathematical Methods in Econom- \\ ics, Hanappi@tuwien.ac.at \& Vienna Institute for Political Economy Research - VI- \\ PER, hanappi@gmail.com
}

\begin{abstract}
This paper investigates how the global class of organic intellectuals will emerge. It thus updates Marx view on class struggle dynamics of the $19^{\text {th }}$ century by taking the quantum leap of productive forces during the last 200 years serious. The most striking new element is the tremendous increase of the force of information power brought about by ICT. The emergence of Fascism and Stalinism in the first half of the $20^{\text {th }}$ century was just a frightening first symptom of the coming age of alienation. Today, basing class membership - including the emergence of class consciousness - only on the (physical) local position in industrial production units is insufficient, even misleading. Global production is by its inbuilt complexity blurring the visibility of a specific worker's exploitation status. There is necessary alienation, but then class struggle managed disinformation and manipulation is added. For the progressive classes this implies that they are split along the lines of their respective education status - how far the fog can be dissolved. This is where the concept of the global class of organic intellectuals, of an avantgarde, enters. The paper shows that already in the emergence of this new socialist agent the structures, in particular the information structures, of the next mode of production have to be present. It turns out that features, which are evil for capitalist thought are often the most important ingredients for the constitution of the forerunners of a socialist global society: persistent contradictions and diversity, exploding oscillations, deep and time-consuming dialogues, irrational solidarity, aesthetic stubbornness. The new intellectuals can remain rooted in local circumstances, can be organic, because they share many of these features with the exploited classes within which they act as catalyst, as avantgarde. In the end global socialism, organised by a revolving class of organic intellectuals, has to master alienation. This is the challenge.
\end{abstract}

Keywords: revolutionary class, alienation, global class of organic intellectuals, political avantgarde, socialism, capitalist algorithm, socialist algorithm

\section{Introduction}

Contemporary social forces are building up steam. It is not just the global climate, which rapidly starts to oscillate with higher and more surprising amplitudes. More and more authoritarian state leaders subscribe to a kind of disintegrating capitalism, which falls back to the coercive mechanisms which were thought to be overcome after World War 2. In this situation a new wave of modernized Fascism knocks at the door and its resonance in the population shows that the progressive movements still have so far not really understood what Fascism is ${ }^{1}$. Their analysis mostly just scratches the surface when it investigates singular historical features of $20^{\text {th }}$ century Fascism. Neither

\footnotetext{
${ }^{1}$ The two classical approaches to explain $20^{\text {th }}$ century are (1) the so-called "Western" interpretation, which equates Fascism and Stalinism as "Totalitarism", and (2) the "Eastern" interpretation, which considers it to be just the rule of most radical imperialistic capitalists. For a critique of both compare Hanappi (2019b).
} 
the personality of Hitler, nor that of Mussolini, nor that of Stalin should be taken as a historical force. Single politicians as well as the local and transient historical peculiarities in which they are embedded in, are of secondary importance if the long-run dynamics of capitalism are to be investigated.

Progressive theory in the tradition of Marx's analysis - what in this special issue is called socialism - has to be envisaged as a theory about the dynamic struggle between classes. The agents of change, those pushing forward social progress as well as those trying to turn back the wheels of history, are large groups with a shared common consciousness, which runs through different stages of emergence. Moreover, even the set of classes to be considered does not stay constant. The last 75 years have seen a tremendous turmoil of emerging and vanishing class consciousness, pseudo-consciousness, misconceived class relationships, mixtures of class, race, and nationalism, and the like.

In short: this confusion indeed was the fertile ground that the dominant economic theory of the ruling class, i.e. neoclassical economic theory, had proposed with its methodological individualism. If human individuals are the uniquely possible starting point for any social theory, if classes are assumed not to exist, then some surrogate Newtonian mechanics framework (neo-classical theory) can be used to show formally that we live in the best of all possible worlds; no change needed. Just make sure that political institutions never disturb market forces. In such a theory, progressive classes do not exist, neither does their enemy, the capitalist class. For the former, the teaching of such a theory is a tranquillizer, a distraction directing attention away from the understanding of social dynamics and substituting it by acquiring mathematical skills appropriate for $19^{\text {th }}$ century physicists. For the ruling classes such a theory is useless as well - apart of its manipulative task with respect to their enemies.

When Fascism did strike after World War 1 the capitalist class could not use its theory to understand what is going on. It had to rely on somebody without education in economics, but with the ability of marrying political skill with convincing rhetoric and a good sense of feasibility: John Maynard Keynes. His doctrine, known as Keynesian macroeconomics, could hide the class concept behind a veil of accounting relationships and an assumed average behaviour of individuals, so-called socio-psychological constants. An approach good enough to re-introduce the state as an institution that is needed to save capitalism from its own aggravating sequence of heavier and heavier crisis. Some former leaders of the labour movement could be pacified by transferring the class struggle to the couloirs and meeting rooms of state institutions. Integrated capitalism was born, and after the little understood intermezzo of Fascism could flourish to its global zenith. Class, as a central concept of political economy, was eliminated from the theoretical discourse.

But as a motor of real economic processes classes were as vital as always, just theories had gone astray. Of course, class structures were changing since Marx's death in 1883 - not a big surprise. Changes in the capitalist mode of production, discrete steps of its development leading to different stages of capitalism, are to be understood in front of what is common to all stages, of what is the essence of capitalism. Capitalism is a particular mode of production embedded in the larger category of commodity producing societies. Commodity exchange - a consequence of the division of labour - implies the emergence of money, which in turn is accompanied by the stepwise evolution of money forms and their corresponding forms of political organisation. Hence, the capitalist mode of production is characterised by a particular money form, which best can be understood as an algorithm. 
In recent discourses the concept of an "algorithm" has taken on a somewhat mystic character, so let me clarify its use in this text. With the shift of formalisation techniques from classical mathematics towards computer programs several important new twists of understanding of processes were implied. A programme running on a computer is an algorithm, i.e. it performs a sequence of instructions, which change the set of variables present in the programme. Though the number of instructions is finite, the possibility of recursive calls of itself within a program - realised in the machine by constructing copies of the calling program - leads to a new understanding of infinity, called the "halting problem" in computer science ${ }^{2}$. From a more profane view, in a finite world programmes need a stop condition since the space for storing copies is finite. The stop condition thus links the external conditions of the programme's environment (its limits) to the general set of instructions. To do this it must be included in the programme. A second important twist stems from an extension of the concept of a variable. A variable is a sign referring to another sign, where at the so-called roots of such a sign structure usually signs referring to measurable properties of non-signs occur. With modern learning techniques sign systems can be derived directly from the interaction between the learning program and these (dynamically changing) roots - though, of course, several axiomatic restrictions of the learning algorithm (often disguised linearity) have to be considered. Unlike the stop condition, which points at the preliminary character of all recursive thinking in real life, the wide opening of self-constructing programmes ${ }^{3}$ due to machine learning has blurred the common perception that programs still are necessarily deterministic. They are written and implemented by human individuals to run in a finite world.

An order given by a firm owner to one of its employees is an algorithm too. It is a sequence of actions, which the employee has to perform. In a specific firm each abstract command will refer to a less abstract action, which the worker has to accomplish - often in more direct physical contact, important for the production process. The boss is the programming authority. The worker is the machine. Note that recursive calls now assume a different flavour: Employees higher up in the firm hierarchy become copies of the boss (or the next higher level) at the interface to the next lower level. The stop condition now simply is the worker who has no other workers subordinated to him/her, i.e. the level where there are workers that do not give orders.

But the real crux that enabled the capitalist mode of production was the evolution of money forms taking place in capitalism: A capitalist owner does not just own a specific firm, he or she rather handles capital, i.e. as a class capitalist owners gain the flexibility to jump from one firm to another firm, from one country to another country, from one tax regime to another tax regime, etc. This new flexibility substitutes the inflexible family bonds, which held the feudal class together, and makes the capitalist class a more abstract class. The only common element in all parts of capital in the world that has to contrast this overwhelming flexibility is what I call the "capitalist algorithm". It is an algorithm again, which can be spelled out very clearly, see below (section 2). Just like recursions the capitalist algorithm can spread, can enhance feudal societies, and can counteract like a disease in societies at the verge to socialism. Like

${ }^{2}$ On a very general level the halting problem is one of the logically undecidable problems as Alan Turing showed (see Turing 1937). There is no possible algorithm that can free a programmer from the need to shut down an otherwise infinitely running programme in all cases. A somewhat disappointing result, though an infinitely running capitalist algorithm is illusionary due to the physical finiteness of the world anyway.

${ }^{3}$ Conceptually self-constructing programmes have already been studied by John von Neumann (1966). For an implementation, see Pesavento (1995). 
cancer, it can disguise as a promised growth process for individual humans, while it actually only addresses capital, and even its individual human agents are forced into its spell - they are just character masks.

This is just the first inhuman aspect of the capitalist algorithm: it enslaves all human individuals of all classes. The second inhuman aspect emerges due to the fact that at the lowest level of the recursive command chain in a social system there is not just a copy of an algorithm for which no additional space in the working memory can be found - as it was the case in a computer. The very reason for the running of the overall programme in this case is unmistakably specified, it is exploitation: there is no room for a human programmer to play around with a toy problem.

At the roots of society an anti-thesis is forming, as Hegel would have called it. It is something that non-living software due to its missing consciousness never will be able to achieve. From all parts of the enslaved humanity, but substantially from these exploited roots, resistance against the capitalist algorithm can constitute itself. It certainly will need to present a different algorithm in its fight against the capitalist algorithm. This algorithm will be characterised by strong and sophisticated feedback loops from the roots of a global society - what today might be called future democracy, socialism, or dictatorship of the proletariat. The design of such a socialist algorithm will bring current attempts in machine learning studied in academic circles to flourish. And it will imply a new money form overcoming capital. An educated guess is that the foundations of this money form are labour time and lust.

The concept of an algorithm thus has emerged as an important concept, and is here to stay with us. In capitalism the capitalist algorithm is the most general abstract programme that governs capital, currently the highest money form of frozen, appropriated social value. The next mode of production will need a governing programme, an algorithm, too. But instead of an illusionary unstoppable accumulation imperative this algorithm will aim at what now is at best a side constraint: (1) compatibility with environmental limits and (2) abolition of exploitation of "humans by humans", feedback loops and diversity instead of hierarchical authoritarian power structures.

\section{The Capitalist Algorithm}

In societies dominated by agriculture, contradictions between cities, i.e. places of exchange, points of concentrated political power, and the open land were aggravating. Exploitation, i.e. the appropriation of surplus by a ruling class, was managed either by direct coercive force - in the beginning the domain of the feudal class - or later by enforcing rent payments in the form of money, i.e. a system of carriers of social value, e.g. coins. The necessary acceptance of this carrier system had, of course, to be secured by the feudal state. With further sophistication of the monetary exploitation system the ruling class experienced a split: On the one hand the politically governing old feudal class and on the other hand the non-feudal merchants which were able to keep the difference between bought and sold commodities as private money stock. In the sequel the latter were the part of the ruling class that provided credit for the nobility, with which then an army of mercenaries could be hired for internal and external exertion of direct power. These soldiers (including administrative military personnel of the state) constituted a further split within the ruling class.

The fruits of the global division of labour which started with the discovery and exploitation of new continents (e.g. in 1492) made merchants cooperating with the crown 
rich. Merchant capitalism was the first monetary program following the capitalist algorithm. This algorithm looks as follows ${ }^{4}$ :

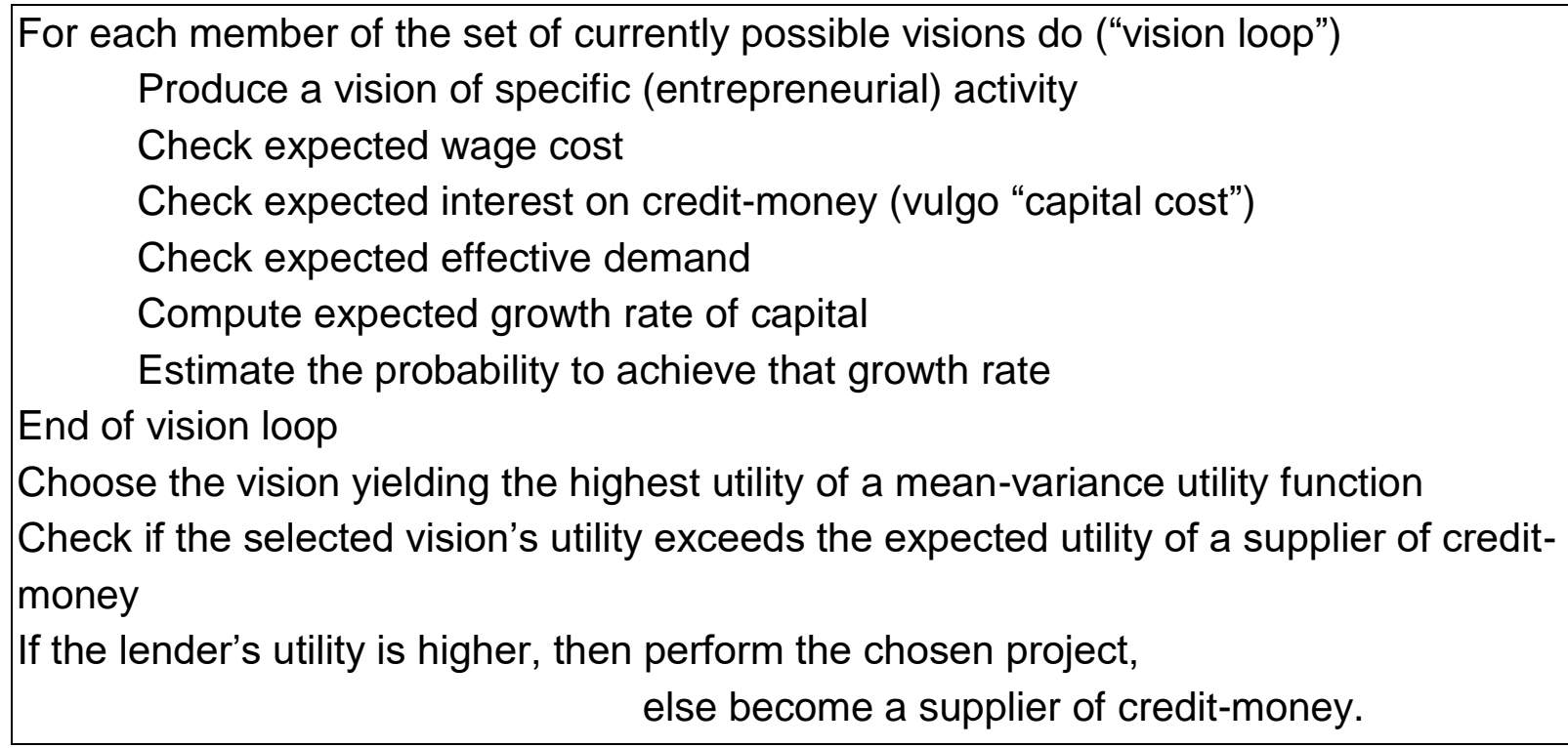

For merchant capital its entrepreneurial component was still somehow hidden below the dominance of the political might of the necessary feudal sovereign. Spanish, Portuguese, Dutch, and British conquerors were "explorers", though their visions already concerned the accumulation of capital stock 5 .

The close connection between profit made by merchant companies and the territories conquered and exploited by the feudal state enabled the ruling classes to keep their contradictory goals most of the time latent. A more pressing problem were the fetters of limited productive force, which the growth process inscribed in the capitalist algorithm soon met. E.g. the capacity to manufacture the amount of cotton transported to England by the merchants from the cotton fields of America was soon reaching its limit. At this point in time the magic word of "innovation" became the new mantra, became a systematic force in capitalism. Innovation designates activities which transform a combination of existing, but seemingly unconnected elements into a new social practice. In capitalism this new social practice typically concerned the activities of a production unit, of a capitalist firm. This narrower concept of innovation nevertheless included at least three elements: technical innovation, organizational innovation, and product innovation.

It is evident that the ability to perform innovation was not a very common property in the group constituting the politically ruling feudal class. The nobility were the degenerated heirs of lucky and brave knights that made their fortunes in the times of direct coercive power struggles ${ }^{6}$. Thus it soon became clear that the ruling classes approached a further split: The non-feudal bourgeoisie was dividing into entrepreneurial

\footnotetext{
${ }^{4}$ A detailed description can be found in Hanappi (2013). The algorithm is formulated with the help of an image of capitalist behaviour, which stems from observing firms of fully developed capitalism, though the nucleus of it is already visible in merchant capitalism.

${ }^{5}$ The fascination with gold that is so characteristic for that period is telling.

6 The correspondence between special properties of the members of a ruling class and their historical mission was highlighted by Antonio Gramsci (Gramsci 1930/1999).
} 
capitalists performing innovation and money owners ${ }^{7}$ administering the transfer of the (monetary) fruits of exploitation to the different components of the capitalist system. Since innovation first started to take hold in the factories, in the industries on the island of England, the stage of capitalism that followed merchant capitalism has been named industrial capitalism. In the words of Marx, this industrial capitalism signals the "historical mission" of capitalism, its raison d'être in the evolution of mankind. Entrepreneurial activity increases labour productivity by process innovation and explores the space of human utility dimensions by product innovation. Both are prerequisites for welfare increase of the whole species: work less and derive utility from an expanding universe of consumption and service dimensions. Schumpeter later stylised the fraction of entrepreneurs as the heroes of capitalism, ignoring Marx's conclusion that the disequilibrium process initiated by industrial capitalism will necessarily lead to a revolutionary shake-up: The so-called "productive forces", i.e. the potential welfare increase, is going to run ever faster than the slow changes in class structures, which hinder that such a latent general welfare increase materialises.

The first clash in 1848 was a failure for the bourgeois fraction of the ruling class, the next one in 1918 proved to be its final triumph. Marx's hope that a revolution within the ruling classes could open up the possibility for a takeover of power by the exploited classes turned out to be unjustified. The capitalist algorithm survived both World Wars of the $20^{\text {th }}$ century.

Since the end of World War 1 capitalism developed into a new stage, which I call integrated capitalism $^{8}$. During this stage several new elements of capitalism were emerging:

(1) In the interwar period, capitalist nation states, the administrative political fraction of the ruling class, allowed for some participation of the exploited classes in the policy process - thus the label integrated capitalism.

(2) Integration at the level of nation states was paralleled, sometimes even supported, by a boost of nationalism, which in the end helped the emergence of Fascism and Stalinism. Fortunately, Fascism experienced a heavy blow in WW2, and in 1990 also Stalinism saw a drawback. More recently, nationalism raises its evil head again.

(3) Both elements mentioned above owe a lot to the rise of new information technology. The manipulation of internal model-building activities of human individuals, i.e. the provision of interpretation schemes, has reached unforeseen levels. To exert power by information policy has become the most effective weapon not just for private firms (with omnipresent advertisements) but also for "political entrepreneurs" distorting more traditional class relations. In other words, we are living in an age of alienation. Compared to the previous two centuries, this concept now experiences a boost: Today reigns hyper-alienation.

The common ground of all stages, i.e. the capitalist algorithm, is itself based on the existence of exploitation, the permeating process which it handles in stage-dependent ways.

\footnotetext{
7 This group includes what today is called 'banking' as well as central banks and national (ministries of finance) and international (ECB, IMF, etc.) financial authorities. In the last 170 years this conglomerate has developed a highly sophisticated internal structure, first investigated from a socialist perspective by Rudolf Hilferding [Hilferding, 1910].

${ }^{8}$ Compare Hanappi (2019a).
} 


\section{Stages of Exploitation and Class Dynamics}

Exploitation in its most general sense is the process of the taking away of lifetime of one group of living systems from another. To exploit the growth processes of plants and animals by eating them is how mankind exploits nature ${ }^{9}$. Note that in this case exploitation takes place between species, and that the notion of sustainability is implicitly characterised by the need of the growth process of inputs to the exploiting species has to be at least as high as the demand for them - though the build-up of stocks of inputs can act as a buffer ${ }^{10}$. The notion of the scarcity of inputs thus falls into two categories: inputs from renewable sources (other species) and inputs from finite amounts of material. Only the former qualify as elements of the exploitation process.

As Marx observed, the exploitation of "man by man" is an extension of the exploitation of nature by the human species, which immediately implies that there exist classes within mankind: an exploiting class and an exploited class. The power to exploit characterises the ruling class as the exploited class is characterised by its stagnation at just sustainable levels of reproduction. The transfer of lifetime can be complete, as is the case in the slavery mode of production, or it can be engineered by institutionalized transfer of labour time (corvée), commodity transfer (rent), or money transfer (taxes). The latter three have been different phases of exploitation mechanisms in feudal medieval Europe, designed to keep the exploited class of farmers at the lowest level of sustainability. These steps of exploitation in Feudalism already herald the ascent of money forms as general systems of signs of social value.

In capitalism money forms take over, the capitalist algorithm presented above links the behaviour of the exploiting class to the working of a specific money form, i.e. capital. In all stages of capitalism exploitation therefore can be traced back to the transfer of labour time from the exploited class to the exploiting class, measured in terms of the general sign system of social value, in money terms. A precise ex post formulation of a labour theory of value, which reports this transfer on a global level, is in principle possible, though extremely cumbersome. It has to account not only for the intricacies of myriads of institutional details that emerged in class struggles all over the world, it also has to consider that the oscillations of power struggles between classes, between firms, between sectors of the economy, and between nation states certainly have led to prices that cannot be considered to be "equilibrium prices" in any useful sense.

Nevertheless, ignoring the difficulties of an algorithmic representation of what happened in the world last year, it is theoretically sound to draw a clear border line between the (globally) exploited class and the ruling class of exploiters based on a labour theory of value ${ }^{11}$. In so far Karl Marx's hypothesis on the purification of the class antagonism between capital and labour is still valid. But this overarching structure of capitalism as a particular mode of production of commodity producing societies does not directly translate into a purification of two antagonistic classes. Only during the first half of the $19^{\text {th }}$ century - the time of Marx socialisation - the impressively fast emancipation of an anti-feudal young bourgeoisie parallel to a socialist avantgarde consisting of anarchists

${ }^{9}$ For a formal model - a simple Lotka-Volterra system - of this process compare Hanappi (2006).

${ }^{10}$ Even in advanced texts of Marxist mathematical economists, e.g. Roemer (1981, p. 19), this so-called feasibility condition usually is derived as a flow equilibrium, without mentioning the importance of stock variables. Note that capital is a stock variable!

${ }^{11}$ From the perspective of the labour theory of value there is no middle class, this is the major argument in the paper Hanappi \& Hanappi-Egger (2012). 
and communists gave the impression that a future bipolar constellation of the exploitation structure only waited for a final intervention of communist intellectuals. The avantgarde of communist intellectuals acts as an agent of enlightenment and transforms the working class from a class in itself into a class for itself - so went the argument at that time.

This plan to catalyse a communist revolution until the end of the $19^{\text {th }}$ century failed. But with respect to the transformation of the working class into a class in itself remarkable successes surfaced as the growth of membership in unions towards the end of the $19^{\text {th }}$ century shows. The decisive setback only came with WW1, when the victory of national consciousness over class consciousness - in particular in Germany and France - became manifest (compare Hobsbawm 1990).

How deep nationalist propaganda had entered the minds of the population turned out in the interwar period. With more advanced information technologies even more radical variants of nationalism, racism and fascism, could take hold in the populations of the losers of WW1, Germany and Italy. The fascist movement became the first "class" without economic rooting, a party held together simply by direct paramilitary coercive force and propaganda. A set of simplistic narratives boasted towards a confused audience (with the help of the newly available broadcasting devices) combined with a dubious call for party discipline was the prelude. With the Great Depression of 1929 the fascist movement finally received the necessary economic backing of German warfare industries. The economic upswing of the 1930s still was taking place without a noteworthy fascist theory ${ }^{12}$, it was just the demand induced by fascist war preparation that drove the economy. Of course, the national socialism of fascists was no socialism at all. The choice of the name "Nationalsozialismus" already reveals a typical trick of fascist movements: Sell your slogans as mixtures of incompatible buzz words. A confused slogan will be appreciated by a confused audience. In the end it is just the glitter and glamour of the packaging of the void, which stirs the enthusiasm of the fascist mob. "The medium is the message" was McLuhan's judgement much later.

In Russia the coalition between many farmers and the weak urban proletariat that Lenin had formed to overthrow Czarism had to build a non-feudal state from scratch. Forced industrialisation thus should produce more proletarians while an apparatus of state administrators being communist party members were acting as substitutes for the working class. In 1924, when Stalin after Lenin's death took over, a particular nationalist policy element - "socialism in one country" - was added to this setting. The ruling class in the Soviet Union, de facto the elite of the national communist party, was different from the fascist rulers in that they indeed had a more or less realistic master plan to develop socialism. What they soon started to miss, after Lenin's death even started to suppress, was innovation and creativity, which they substituted by military controlled discipline and correlated hierarchical power structures. The population did develop into a class structure following this hierarchy. On top was the elite of administrators of state power more or less identical with the party leaders. On the levels below there was the management personal with executive power according to their position in the hierarchy. All of them more or less conscious of executing a faint copy of the capitalist algorithm to win what had been called "system competition with the West" by the doctrine of "socialism in one country". Below these classes with graded ruling

12 One of the predecessors of Keynes' ideas, Michail Kalecki, at the time probably had a better understanding of the fascist movement than its proponents, see Kalecki (1943). 
power there was the amorphous mass of workers, which became increasingly tired of policed discipline lacking increases in welfare ${ }^{13}$.

Then World War 2 stopped the proliferating social cancer called Fascism and in the West brought integrated capitalism to its most sophisticated form. In many OECD countries a two-party system served as a simulation of the interplay between a working class oriented economic policy and the goals of the capitalist class. Compromises between these two large parties, including alternate state leadership - became the rule. In the East the Soviet Union had advanced towards Europe and its satellite states became copies of the Russian original. As the latter could build on their pre-war knowledge stock their technologically more advanced commodities became the exports to the USSR which they exchanged for cheap energy. Nationalism in the new states remained as latent as religious attitudes. Only when the systems collapsed around 1990, their social structures rapidly broke up. Quick adopters in the population, often with the help of Western intruders, formed a young capital class that was able to apply the capitalist algorithm in the new environment. In Russia, this class now is called the group of new oligopolists and constitutes a second pillar of the ruling class. There again is a similar, even more pronounced development in China.

But in the early 1970s, integrated capitalism in the West had passed its zenith. The part of the ruling class controlling international finance had concentrated in the USA. To cement its economic dominance the regime of fixed exchange rates was given up, leading to a burst of US exports, a price hike of oil prices and turmoil in two-party systems worldwide. Around 1980, Ronald Reagan, Margaret Thatcher, and Helmut Kohl took office and a long-run downturn of social democratic parties in Europe (and the Democrats in the USA) started. The global capitalist class started again to shape the world economy according to its goals. It followed the capitalist algorithm.

Globalisation now meant that global value chains were booming. Financial centres in the rich world's big cities together with multinational firms looked for countries with low wages and sufficient knowledge for production, other countries with high effective demand, and still other countries to be used as tax havens. The ruling classes were split again into multinational and transnational giant firms on one hand and local national capitalists on the other. State administrations started to align along continental frameworks; the banking sector was already a highly concentrated global network. The capitalist class thus today is characterised by a mosaic of partly opposing entities, though all parts subscribe to their perception of the capitalist algorithm. They mistakenly perceive this algorithm and its growth imperative as an unchangeable "natural" property of mankind.

On the side of exploited classes, the work of the traditional industrial proletariat of OECD countries to a considerable extent has been shifted to $3^{\text {rd }}$ world countries, compare Cope (2015). This element of the globalisation process implied a severe split of the working class. It not only meant that overall representatives of workers do not exist, at best there are some local national leaders. It alenaso implied that the commodities had to be sold to consumers in rich countries, buying with money they received from credits, increasing the debt levels of banks and governments. While wages and commodity prices were - and to some extent still are - the central variables for exploitation within a national economy, the new global setting has replaced them by exchange

${ }^{13}$ The development of China had many similarities to the original Stalinist production system. 
rates and debt levels ${ }^{14}$. The fragility of this global financial system popped up in 2001 as the so-called IT-crisis, and as a real disaster in 2008.

Despite the fact that the global working-class today is atomised as far as its class consciousness is concerned, it nevertheless is more tightly interwoven in the global production process itself than in any time in human history. The leap from a class in itself to a class for itself therefore has widened enormously.

\section{The Emergence of the Class of Organic Intellectuals}

The local environments, the perceived worlds within which workers expend their labour time, remain alien to the quantitative amount of money they receive in return for their activity. If they compare their deal with what happens in distant environments they often simply cannot understand. If then the global financial coordination system gets a blow - the crisis of 2008 probably was just a prelude to the next, really heavy shock it seems to be an unexplainable natural catastrophe, fate, bad luck.

Remembering that the last comparable financial crisis, the Great Depression of 1928 , in the end was only overcome by the war expenses of Fascist regimes heading for WW2 should make us aware that the rise of extreme right-wing parties all over the world eventually is a messenger of a new kind of Fascism, a thunderstorm of a $3^{\text {rd }}$ World War, which with less luck than with the previous one, mankind will not survive. Fascism builds on nationalism paired with a technologically amplified hatred (i.e. a blind feeling) on the bugaboo of an enemy. To fight it, the opposing attitudes and actions have to be launched: global humanism and scientific analysis of social contradictions.

To support a fascist regime is usually not the first choice of a capitalist class. But unfortunately, due to the destructive power of contemporary weapons, even seemingly small conflicts at the periphery involving a handful of "madmen in authority who hear voices in the air" (Keynes 1936, 241) are sufficient to cause a global disaster ${ }^{15}$. With fascism in state power the growth imperative of the capitalist algorithm assumes its ugliest face: military conquest and an internal police state. Compared to the $20^{\text {th }}$ century, today's "surveillance capitalism"16 now possesses means to monitor the individual behaviour of citizens in real time. The problem of a centralised police state is not the availability of this enormous amount of data, the problem is how to select the relevant parts and pieces. To be able to do so, some kind of interpretation of observed messages is mandatory. This starts with the occurrence of certain words and contacts to seemingly suspicious persons. As in the $20^{\text {th }}$ century, it will end with a complete streamlining of communicated independent thought and the burning of (electronic) books. There is a global community which is the carrier of exactly this: the global community of scientists. It will be its vital interest to fight Fascism.

As a matter of fact, contemporary science to a large and increasing extent takes place electronically. Ideas are exchanged, laboratory experiments are performed, reported, simulated with the help of electronic devices. There now exists already a global

\footnotetext{
${ }^{14}$ Note that national government debt is just firm and household debt disguised by the promise of a capitalist nation state to be able to set the record straight by appropriate fiscal policy any time the creditors want it. Left wing actors in governments therefore are always a threat for these creditors, which explains debt problems of left-leaning governments.

${ }^{15}$ In 1936. Keynes was not aware that his prophetic words applied even better to the fascist leaders that are not even "distilling their frenzy from some academic scribbler of a few years back". Fascism is free from any serious theoretical content below the surface of propaganda.

16 The term was recently popularised by Shoshana Zuboff (2019).
} 
community of scientists held together by the various objects of investigation studied and a shared devotion to reveal scientific truth. But note that the same information infrastructure that enables the jump in scientific collaboration has led to a jump in fragility and random outcomes of traditional democratic mechanisms. This is the result of the success of the first three stages of capitalism (merchant, industrial, and integrated capitalism), which have pushed the global division of labour to a level that in the era of global alienation now isolates individuals in perception bubbles with little chances to understand larger parts of their actual economic and political interdependence.

The most important big topics for them look like completely unpredictable white noise, like fate. They are the blank white sheet in front of which the stupid narratives of soap operas and outdated religious ghost stories entertain them. Sure enough, the global structure of production, in particular global value chains, has also left its trace in the structure of the global working class. Despite its common high level of alienation, the part of the proletariat working in third world countries deliver an overload of labour time with minimal room for their own education or political emancipation.

The part of the exploited living in OECD countries acts either as better educated worker or in the administration (including marketing and selling) of the global production process. This latter part is also needed to complete the circuit of exploitation, i.e. to buy the cheaply produced products at prices allowing high enough (always monetary) global profits. This is only possible due to the global system of credits and national government debts. Today's profit of the large and successful firms is made possible by allowing less wealthy, even poor citizens in the rich world to pay later ${ }^{17}$. In many OECD countries that have more developed tradition of the labour movement, this borrowed increase in consumption also acted as a tranquiliser with respect to more radical socialist aspirations: If capitalism manages to make you better off, why should you fight it? And if this experience prevails for decades, then the notion of exploitation vanishes in the minds of the population. Alienation then not only concerns alienated products and alienated, complicated production relationships, it in particular becomes a strangeness with respect to the own status of the now completely alienated individual human being. In such a situation mass psychology becomes very volatile ${ }^{18}$. Political moves of larger groups of such societies become as difficult to predict as the moves of an aggressive tiger.

On the other side of the globe, humans of the Global South live in poverty, in locally encapsulated regions where hard labour in low-paid manufacturing enclaves is organised. In such an environment, there is only little time and communicative space to develop islands of intellectual counterinsurgency. Aggression in such a depressing context sometimes turns to cultural implosion, to a return to outdated religious traditions. Again, this type of revolts is erratic, difficult to predict, and in its high aggressive potential also reminding on the just mentioned tiger.

The problem for a global class of organic intellectuals is that there is no way to ride these tigers with enlightenment arguments - as Marx had hoped to have found the most oppressed class, the proletariat, which only needed its class consciousness (provided by communist intellectuals) to become a class for itself. To some extent, the alienation process is irreversible, the enormously grown human society needs it, needs the division of labour (including the one between manual and intellectual labour) to reproduce itself. What is not needed is the omnipresence of the capitalist algorithm.

17 The alternative to produce more commodities for the super-rich is limited by the tremendous shrinking of the members of this group.

18 With reference to Sigmund Freud's insights, Adorno (1951) discusses how fascism is able to use this volatility. 
Quite to the contrary, this virus of a fading away capitalist mode of production again and again jumps on the train of authoritarian, fascist movements supporting their war preparations (and wars) for profitable short-run investment. World War 3 is knocking at the doors of human history; there is no good reason why this history might not end with the capitalist mode of production - though certainly not in the paradise that the prophets of capitalism (as nature's final goal) had promised.

The global class of organic intellectuals, as a conscious part of the exploited people in the world, therefore needs an add-on to the self-imposed "enlightenment"' - to its own knowledge acquisition - that enables it to interact with the poor South as well as with the hyper-alienated rich North. Today scientists and intellectuals are dispersed all over the world and serve very different class interests rooted in the wide variety of human cultures. Large parts of this group already strive for progress of humanity in a very general sense, to know induces to be left-leaning. But these are not a proper class yet. That they develop into the global class of organic intellectuals is still a desideratum. So far the original class background of the future members of this new class is less important, due to a worker's little time left to become an intellectual it is even more probable that a considerable part originally does not come from working class families. But as they become "organic" they transform themselves into a vital part of this newly emerging class, which then forms a tight coalition with the most exploited parts of the global working class ${ }^{19}$.

To be "organic" means to be closely connected to the poor South and the hyperalienated rich North, while nevertheless to have some stand-alone capabilities. Connections as information flows come - actually are in principle already available - via the global information infrastructure. Connections in a more physical sense, i.e. connections as commodity and service flows, are still waiting to be designed - on a global level, of course. In other words, it is democracy itself that waits to be transformed from an antediluvian rule of majority voting to a pragmatic design of global reproduction of the species ${ }^{20}$. This would be the riding of the tiger.

\section{Afterthoughts}

For the just mentioned design political economy needs a substantial remake of what mainstream economic theory provides today. Most types of equilibrium assumptions make only sense if some extremely fast processes are included in models of extremely slow processes. For processes taking place in approximately the same range of speed, e.g. in political economy dynamics, there is no place for (general) equilibrium theories. They have to be replaced by formalisms that grasp dynamic instability, increasing disequilibria, structural instability and emergence and exit of relevant variables. For theoretical physics and biology some formalisations of this kind - often using algorithmic formalisms - already exist, the social sciences are lagging behind. Synthesis of the different sciences with respect to the formalisms used thus is getting even more important.

But not only formal techniques need an upgrade. Looking at the objects of investigation also reveals a necessary turn of attention. The spell of being concerned only

${ }^{19}$ The global production structure today is organised mainly along global value chains (see Suwandi 2019). Therefore, the different strata of exploitation strength are geographically mirrored. This is an important source of information for the newly emerging class.

20 To square the potential of the internet with the need to develop democracy also is in the focus of the work of Eugenia Siapera (2017). 
with the economy within the borders of a nation state obscures most scholarly communication. This is evident in microeconomic theory that explicitly assumes away influences of a capitalist political entity called the state. In macroeconomic theory this state is added again, while the misspecifications of a representative household and a representative firm are dropped to make room for underspecified behavioural aggregates that shall substitute classes. But what remains almost completely out of sight is the level of the (really finite) world economy ${ }^{21}$. In times of global value chains and global finance, the largest scope, the world economy, has to be political economy's first focus. But since political economy needs at least two focuses to bring in additional dimensions (compare our eyes), there also has to be a complementary second focus. We need to give attention to the diversity of perceived dynamics of political economy in different locations in the world.

Producing an abstract global model (first focus), which aspires to grasp the essentials adequately, is not a matter of freewheeling theoretical invention. Its abstract assumptions have to be derived (in Marx' words produced as "Gedankenkonkretum", a "totality of thoughts" that is "concrete in thought", Marx 1857/58, 101) by finding shared elements in a great diversity of local observations. To perceive these local dynamics (second focus) - including the mental models of the local classes involved - is an indispensable precondition for useful abstractions of the first focus. Since the two eyes of the scientist are interdependent, how local dynamics are observed also is framed by the global view. A conscious and close interaction of the two perspectives, global and local, bridging generalisation and Schumpeterian diversity ${ }^{22}$, shall be a permanent aspiration.

Diversity is here to stay, though in ever-changing forms. This provides a possible answer to the question: What is so socialist about the global class of organic intellectuals, anyway? To start with, the currently observed result of several hundreds of years of capitalism is significant enough. The capitalist algorithm has produced an enormous split - a diversity - of wealth and income in the world ${ }^{23}$. At the same time, it has also led into a bewildering diversity of perceptions of what is going on. This is the experience of an age of alienation. The globally possible information overload in the communication sphere now mainly consists of advertisements and manipulative messages, which indeed mute any communication. In this way the capitalist mode of production has undermined the possibility of a democratic global political economy, it currently could tilt over to a reprise of autocratic authoritarian regimes fighting each other in a Third World War (compare Hanappi 2019a). Capitalism enters its self-destructing last stage.

The hope is that it can be decoupled from the fate of the human species. If the global class of organic intellectuals ${ }^{24}$ can contribute to this decoupling, this is exactly

${ }^{21}$ Open economy models of macroeconomics are an insufficient attempt to cope with this absence. They usually start with a two-country case and then eventually jump to the infinitelymany countries case - for technical convenience, of course. Needless to say that such models are rather inadequate for a treatment of the world economy, since they are based on a "representative" macroeconomic country model.

${ }^{22} \mathrm{Re}$-occurring diversity is as important as its counterforce of sudden singling out of temporary Schumpeterean heroes. This idea already has been the mantra of Darwin's evolutionary view in biology. This type of diversity is what here is called "Schumpeterean diversity". For a model of an "optimal" level of diversity (see Hanappi and Hanappi-Egger 2004).

${ }^{23}$ Note that these distributions are epiphenomena caused by exploitation.

${ }^{24}$ Being "organic" in this context means to be on the side of the human species, on the side of "living labour" instead of "dead labour", i.e. capital (the capitalist algorithm), as Marx once remarked: "Indem der Kapitalist Geld in Waren verwandelt, die als Stoffbildner eines 
what can be called "socialist". Of course, if the catastrophe can be prevented, then the diversity of the global population remains intact, organic intellectuals will be just one element of it. They will work on an elimination of the most painful type of diversity today, the one in living conditions around the globe, and at the same time they will try to spur the diversity of utilities which the locally dispersed communities are able to experience. In both respects, several thresholds will have to be respected:

(1) Mankind is also a system of biological entities. Thus, it needs a minimum of reproducible resources to survive, which limits its own reproductive activities. To care for sustainability in a world where also self-reproducing inputs (plants and animals) have rather finite growth rates, means to be restrained by a complicated network of checks and balances.

(2) As a species, mankind builds up neg-entropy. But it nevertheless is embedded in the long-run increase of entropy, i.e. it was born and will die. Birth and death reduce human individual experience to a much shorter period than the one of the species. As a consequence, the knowledge capacity of any human individual is much smaller than the knowledge capacity of the species. It is the diversity of finite knowledge capacity appearing in different communities (storing a medium-time experience), human individuals (storing a short-time experience), and human society's knowledge (storing the long-time experience), which in its interwoven status restricts what each of these entities can communicate, what it can transmit to other entities. These limits of knowledge acquisition ${ }^{25}$, of learning and teaching, are not only dispersed along the dimension of time of experience, they are also dispersed with respect to geographic location.

(3) A third limit, which usually is ignored, concerns a property that in physics is known as inertia. For a social entity this property means that its inscribed procedures will be repeated unchanged if no stimulus is forcing a change. Such a stimulus can come from suddenly changing environmental conditions, or from internally built expectations, both reasons often being interconnected ${ }^{26}$.

For the global class of organic intellectuals, it is most important to learn from the just mentioned limitations ${ }^{27}$. From limitation (1) it becomes clear that the adjective "organic" also has to cover the fact that animals, plants, and non-living scarce resources have to be explicitly included in any design of a new mode of production. This was not the case when the outgoing capitalist algorithm emerged, which still reaches for the unbound growth of the capital stock. From limitation (2) a more modest, a more realistic

neuen Produkts oder als Faktoren des Arbeitsprozesses dienen, indem er ihrer toten Gegenständlichkeit lebendige Arbeitskraft einverleibt, verwandelt er Wert, vergangne, vergegenständlichte, tote Arbeit in Kapital, sich selbst verwertenden Wert, ein beseeltes Ungeheuer, das zu ,arbeiten' beginnt, als hätt' es Lieb' im Leibe” (Marx 1867b, 209). English translation: "By turning his money into commodities which serve as the building materials for a new product, and as factors in the labour process, by incorporating living labour into their lifeless objectivity, the capitalist simultaneously transforms value, i.e. past labour in its objectified and lifeless form, into capital, value which can perform its own valorization process, an animated monster which begins to 'work', 'as if its body were by love possessed'" (Marx 1867a, 302).

25 The ability to forget the correct less important parts of knowledge in time never has to be forgot as a constitutive part of the learning process.

${ }^{26}$ In the $19^{\text {th }}$ century, the upheaval of the working class was stimulated by the expectation that the lives of workers will be condemned to misery forever if they would not start a communist revolution. On the other hand, reactions on an approaching climate catastrophe are fuelled by direct perceptions of sudden environmental changes as well as by expectations formulated by climate science.

${ }^{27}$ Compare the use of game theory for studying limits, as proposed by Herb Gintis (2014). 
vision of enlightenment has to be derived. The idea that knowledge only flows topdown, from an intellectual elite to an unconscious mass of less educated individuals, this idea has to be rejected. In the end this idea has been at the core of the religions that dominated early stages of human evolution: an omniscient entity (God) is governing what human knowledge can achieve. Instead, the mentioned structural limitations show that knowledge flows in all directions: between communities (often dubbed "cultures"), within the members of communities and classes, between global knowledge and all other entities (often using the internet). The distinction between different channels, as already mentioned in the previous chapter, therefore becomes very important.

The preliminary character of all knowledge, of course, does not nullify the fact that there is a grading from less adequate to most adequate knowledge. The push towards upgrading on all levels and for all entities for the next mode of production via communication is the final step ending religions, substituting them by rules of commensurate behaviour. Nevertheless, also in this field some diversity will persist, Schumpeterean diversity. The lessons taken from limitation (3) are straightforward extensions from the previous points. Why should a social entity - a human individual, a community, a class, society as a whole - change its course of behaviour? The first, the most evident reason is that the dominant behaviour has changed its environment in a way that makes survival with the same behaviour impossible. Like an asteroid that is led by its physically determined trajectory into a planet: without consciousness a crash is inevitable. Inertia in a society does exist too.

The only remedy to prevent a crash in living systems is by building expectations, which in turn are built on memories. Memories can be grouped in two categories, good ones and bad ones ${ }^{28}$. When expectations for the future trespass a certain sensitivity border as compared to the current situation, then a social entity will surmount inertia. If something very bad pops up or if something particularly nice can be expected, then regular behaviour will be overridden by a new type of action. The lesson for the global class of organic intellectuals follows straight from this observation: The situation of the global working class exploited in third world countries (mainly in manufacturing) keeps it in a state of despair that continuously breeds radical hate and energy to change their fate. For them, fuelled by bad expectations based on bad memories, organic intellectuals have to provide designs of a future global mode of production that give them hope. This is complicated and includes strategies on how to get from here to there, but it is possible.

For the population in the richer part of the world, where the age of alienation has arrived at a fragile state of confusion, the immediate danger is a return of nationalism leading to fascism and as a consequence to global war. It has to be noted that nationalism also works with expectations, with the propagation of a seemingly extremely glorious future. It promises the re-birth and domination of a grand nation ("to make the nation great again"). The fight of organic intellectuals against fascism in the area of ideology therefore has to demolish this illusion scientifically and has to provide a vision of love and peace for all women and men as alternative. The latter is not a scientific project. It is an emotional message rooted in the acceptance of the preliminary character of scientific knowledge, in the acceptance of the sensual, of the aesthetic remains of human perception. It might be difficult to learn for intellectuals that influence on others, empathy with others, is also based on channels that are not using knowledge, but

${ }^{28}$ Why and how these two types of memories are emerging goes far beyond the scope of this paper. It only has to be noted that the two categories always have to be linked to the consciousness of the respective social entity. 
somehow accept its limited character. These channels are using beauty and lust - and as history teaches any social movement neglecting them is doomed to fail ${ }^{29}$. To ride the tiger of alienation in an age of alienation the class of organic intellectuals will have to develop its aesthetic attraction too!

These paragraphs are not a closing conclusion. They are an open invitation to develop further ideas on how to proceed. With each movement of the tiger below us our reactions must be rational and intuitive at the same time, such are the living conditions of the class of organic intellectuals.

\section{References}

Adorno, Theodor W. 1951. Freudian Theory and the Pattern of Fascist Propaganda, ed., in The Culture Industry, edited by Jay M. Bernstein, 132-157. London: Routledge.

Cope, Zak. 2015. Divided World Divided Class: Global Political Economy and the Stratification of Labour Under Capitalism [2nd Edition]. Montréal, Canada: Kersplebedeb.

Gintis, Herbert. 2014. The Bounds of Reason: Game Theory and the Unification of the Behavioral Sciences. Princeton: Princeton University Press.

Gramsci, Antonio. 1930/1999. Further Selections from the Prison Notebooks. London: Electric Book Company.

Hanappi, Hardy. 2019a. From Integrated Capitalism to Disintegrating Capitalism. Scenarios of a Third World War. SCIREA: Journal of Sociology 3 (3): 102-128. Preprint working paper version: MPRA 91397. Accessed 4 November 2019. https://mpra.ub.unimuenchen.de/91397/

Hanappi, Hardy. 2019b. The Roots of Fascism. Shit Happens? Working paper version as MPRA.

Hanappi, Hardy. 2013. Money, Credit, Capital, and the State: On the Evolution of Money and Institutions. In The Two Sides of Innovation. Economic Complexity and Evolution, edited by Guido Buenstorf, 255-282. Heidelberg: Springer. Accessed 3 December 2020. https://www.econ.tuwien.ac.at/hanappi/Papers/Hanappi 2013c.pdf

Hanappi, Hardy. 2006. Endogenous Needs, Values and Technology. Evolutionary Economic Modelling to Replace Microeconomics and Macroeconomics. Paper presented the European Association for Evolutionary Political Economy (EAEPE) Conference 2006 in Istanbul (Turkey), November 2-4, Istanbul, 2006. Published as MPRA Paper No. 28880. Accessed 4 November 2019. https://mpra.ub.uni-muenchen.de/28880/, https://www.econ.tuwien.ac.at/hanappi/Papers/eaepe 2006.pdf

Hanappi, Hardy and Edeltraud Hanappi-Egger. 2012. Middle Class or in the Middle of a Class? Paper contributed to the joint AHE/FAPE/IIPPE conference in Paris, 5-8 July 2012. Accessed 4 November 2019. https://www.econ.tuwien.ac.at/hanappi/Papers/Hanappi Hanappi-Egger 2012b.pdf

Hanappi, Hardy and Edeltraud Hanappi-Egger. 2004. New Combinations. Taking Schumpeter's Concept Serious. Paper presented at the International Schumpeter Society Conference 2004 in Milano (I), June 9-12, Bocconi University, 2004. Published as MPRA Paper No. 28396. Accessed 4 November 2019. https://mpra.ub.uni-muenchen.de/28396/

Hilferding, Rudolf. 1910. Das Finanzkapital. Eine Studie über die jüngste Entwicklung des Kapitalismus. Vienna: Wiener Volksbuchhandlung (Marx-Studien, Vol. III).

Hobsbawm Eric J. 1990. Nations and Nationalism Since 1780. Cambridge: Cambridge University Press.

Kalecki, Michal. 1943. Political Aspects of Full Employment. Political Quarterly 14 (4): $322-$ 331.

${ }^{29}$ As the cultural rebellion of the 6o-ties shows, the reverse is not necessarily true - though it is still an open question if this rebellion failed in a long-run perspective. 
Keynes, John M. 1936. The General Theory of Employment, Interest, and Money. Adelaide: The University of Adelaide Library Electronic Texts Collection. Accessed 4 November 2019. https://ebooks.adelaide.edu.au/k/keynes/john maynard/k44g/index.html

Marx, Karl. 1867a. Capital Volume 1. London: Penguin.

Marx, Karl 1867b. Das Kapital Band 1. MEW Band 23. Berlin: Dietz Verlag.

Marx, Karl. 1857/58. Grundrisse. London: Penguin.

Pesavento, Umberto. 1995. An Implementation of von Neumann's Self-Reproducing Machine. Artificial Life 2 (4): 337-354.

Roemer, John. 1981. Analytical Foundations of Marxian Economic Theory. Cambridge: Cambridge University Press.

Siapera, Eugenia. 2017. Understanding New Media. London: SAGE.

Suwandi, Intan. 2019. Value Chains: The New Economic Imperialism. New York: Monthly Review Press.

Turing, Alan. 1937. On Computable Numbers, with an Application to the Entscheidungsproblem. Proceedings of the London Mathematical Society 42 (1): 230-265.

von Neumann, John. 1966. The Theory of Self-Reproducing Automata. Urbana: University of Illinois Press.

Zuboff, Shoshana. 2019. The Age of Surveillance Capitalism. The Fight for a Human Future at the New Frontier of Power. New York: Profile Books.

\section{About the Author}

\section{Hardy Hanappi}

Hardy Hanappi was born in Vienna (1951) and studied economics and Informatics. He became university professor and researcher at the University of Technology of Vienna and concentrated on macroeconomics, political economy, simulation methods, and game theory. He was deputy director of socioeconomics at the Austrian Academy of Sciences, and director of the Institute for Monetary Economics (Ludwig Boltzmann-Institute). From 2004 till 2016 he was Scientific Development Officer of the European Association for Evolutionary Political Economy. From 2011 to 2015 he was professorial research associate at SOAS (University of London). He currently is ad personam chair for Political Economy at the European Commission and director of the Vienna Institute for Political Economy Research (VIPER). For more details on his curriculum vitae see http://www.econ.tuwien.ac.at/hanappi/cv Hanappi.pdf

$\mathrm{He}$ has been project leader of numerous research projects and author of more than 200 publications (see http://www.econ.tuwien.ac.at/hanappi/publications.html). After his retirement from the TU Vienna in October 2017 he still is providing the annual lecture series in "Political Economy of Europe" and "Information Economics".

Besides global political economy his most recent research interest concerns the development of quantum political economy. He is married to professor Edeltraud Hanappi-Egger, has three children and lives in Vienna. 